\title{
Molecular characterization of indigenous Bacillus thuringiensis strains isolated from Kashmir valley
}

\author{
A. L. $\operatorname{Reyaz}^{1} \cdot$ L. Gunapriya ${ }^{1}$ P. Indra Arulselvi ${ }^{1}$
}

Received: 18 May 2016/ Accepted: 30 January 2017/Published online: 8 June 2017

(C) Springer-Verlag Berlin Heidelberg 2017

\begin{abstract}
Bacillus thuringiensis (Bt) being an eco-friendly bioinsecticide is effectively used in pest management strategies and, therefore, isolation and identification of new strains effective against a broad range of target pests is important. In the present study, new indigenous $B$. thuringiensis strains were isolated and investigated so that these could be used as an alternative and/or support the current commercial strains/cry proteins in use. For this, 159 samples including soil, leaf and spider webs were collected from ten districts of Kashmir valley (India). Of 1447 bacterial strains screened, $68 \mathrm{Bt}$ strains were identified with 4 types of crystalline inclusions. Crystal morphology ranking among the $B t$ strains was spherical $(69.11 \%)>$ spore attached $(8.82 \%)>\operatorname{rod}(5.88 \%)=$ bipyramidal $(5.88 \%)>$ spherical plus rod $(4.41 \%)>$ spherical plus bipyramidal $(2.94 \%)=$ cuboidal $(2.94 \%)$. SDS-PAGE investigation of the spore-crystal mixture demonstrated $B t$ strains contained proteins of various molecular weights ranging from 150 to $28 \mathrm{kDa}$. Insecticidal activity of the 68 indigenous $B t$ strains against Spodoptera litura neonates showed that $B t$ strain SWK1 strain had the highest mortality. Lepidopteron active genes (cryl, cry $2 A b$, cry $2 A b)$ were present in six $B t$ strains. Further, analysis of a full-length cry $2 A$ gene $(\sim 1.9 \mathrm{~kb})$ by PCR-RFLP in strain SWK1 revealed that it was a new cry $2 A$ gene in $B t$ strain SWK1 and was named as cry2All (GenBank Accession No. KJ149819.1) using
\end{abstract}

Electronic supplementary material The online version of this article (doi:10.1007/s13205-017-0756-z) contains supplementary material, which is available to authorized users.

P. Indra Arulselvi

iarulselvibiotech@gmail.com

1 Plant and Microbial Biotechnology Laboratory, Department of Biotechnology, Periyar University, Salem, India the $B t$ toxin nomenclature (http://www.btnomenclature. info). Insect bioassays with neonate larvae of $S$. litura and $H$. armigera showed that the purified Cry2Al1 is toxic to $S$. litura with $\mathrm{LC}_{50} 2.448 \mu \mathrm{g} / \mathrm{ml}$ and $H$. armigera with $\mathrm{LC}_{50}$ $3.374 \mu \mathrm{g} / \mathrm{ml}$, respectively. However, it did not produce any mortality in third instar larvae of Aedes aegypti, Culex quinquefasciatus and Anopheles stephensi larvae/pupae insects $(100 \mu \mathrm{g} / \mathrm{ml})$ at $28 \pm 2{ }^{\circ} \mathrm{C}$ and 75 to $85 \%$ relative humidity under a photoperiod of 14L:10D.

Keywords Bacillus thuringiensis · Cry protein · cry2All gene $\cdot$ Kashmir $\cdot$ PCR-RFLP $\cdot$ Spodoptera litura

\section{Introduction}

Bacillus thuringiensis is ubiquitous, Gram-positive, sporeforming bacterium that is characterized by the production of insecticidal crystal proteins known as $\delta$-endotoxin (Shishir et al. 2014). These have a great potential to control a number of insect pests belonging to Lepidoptera, Diptera and Coleoptera and are benign to the environment (Schnepf et al. 1998; Zhong et al. 2000; Vidyarthi et al. 2002; Valicente et al. 2010). There are reports of $B t$ strains active against livestock ectoparasites (Gough et al. 2002) and nematodes (Wei et al. 2003). Recently several reports of $B t$ and its toxicity against various insect pests have been documented (Ozturk et al. 2008; de Escudero et al. 2014; Neethu et al. 2015). Cry toxins' primary action is to lyse midgut epithelial cells by inserting into the target membrane and forming pores (Bravo et al. 2007). Commercial $B t$-based bioinsecticides used worldwide are applied at $10-50 \mathrm{~g} /$ acre or about $10^{20}$ molecules/acre, while chemical pesticides such as organophosphates and pyrethroids are applied about $8 \times 10^{24}$ and $3 \times 10^{22}$ molecules/acre, 
respectively. Thus, the molecular potency of these toxins is 80,000 times better than organophosphates and 300 times greater than synthetic pyrethroids (Feitelson et al. 1992). Ever since the cloning of first cry gene (crylAa) from $B$. thuringiensis spp. kurstaki HD-1 (Schnepf and Whiteley 1981), 304 such cry holotype protein genes have been reported (Crickmore et al. 2016; 25th April 2016, http:// www.btnomenclature.info/). These insecticidal crystal protein genes are the major source for the development of insect-resistant transgenic plants (Romeis et al. 2006). Genetically engineered crops which produce insecticidal proteins of $B t$ for the control of pests have been planted on a cumulative total of $>560$ million hectares worldwide since 1996 (James 2013). However, there have been some tribulations with this approach, for instance narrow insecticidal range and evolution of insect resistance (Sumerford et al. 2013; Pardo-López et al. 2013; Gassmann et al. 2014). An investigation of 24 cases, with each case relating responses of single pest species in one country to an individual $B t$ toxin, demonstrated that the practical influence of field-evolved resistance can differ from none to severe, based on the magnitude, incidence and spatial distribution of resistance (Tabashnik et al. 2014). Hence, isolation of new $B t$ strains with novel toxins are of significance for providing alternatives to these problems. In this regard, the present study was carried out to explore diversity of $B t$ present in samples collected at Kashmir valley (roughly between $32^{\circ} .15^{\prime}$ to $37^{\circ} .05^{\prime}$ North latitude and $72^{\circ} .35^{\prime}$ to $83^{\circ} .20^{\prime}$ East longitude) situated at the northern western tip of Himalayan biodiversity hotspot (Mittermeier et al. 2005). This may yield new Bt strains with novel cry gene sequences which could encode crystal proteins with significant difference in the level of toxicity due to variation in their sequences.

\section{Materials and methods}

\section{Reference strain}

Bacillus thuringiensis subsp. kurstaki HD1 was obtained from Bacillus Genetic Stock Center (Columbus, Ohio) which served as positive control.

\section{Sample collection and bacterial strains}

A total of 159 samples from different spots in ten different divisions (Anantnag, Kulgam, Pulwama, Shopian, Budgam, Srinagar, Ganderbal, Bandipore, Baramulla and Kupwara) of the Himalayan valley Kashmir, India were used for isolation of $B t$ (Online resource 1). To our best knowledge, $B t$ insecticides had not been formerly applied in the sampled areas. All the soil samples (each $\sim 5 \mathrm{~g}$ ) were collected from 2 to $4 \mathrm{~cm}$ below the surface after scraping off the surface material with a spatula. Leaf samples were collected from dense forest areas to get the maximum microbial population. Spider webs were collected using sterilized small sticks. All the samples were stored in sterile screw-capped vials.

\section{Isolation and maintenance of $B t$ strains}

Isolation of $B t$ strains from the samples was performed according to the method described by Ramalakshmi and Udayasuriyan (2010). In the laboratory, one gram of sample was suspended in $10 \mathrm{ml}$ of sterile distilled water $\left(10^{-1}\right)$ in a boiling tube. The boiling tube was kept at $65^{\circ} \mathrm{C}$ for $30 \mathrm{~min}$ and allowed to settle. One milliliter of this treated suspension was added to four $\mathrm{ml}$ of saline $(0.85 \%$ $\mathrm{NaCl}$ ), which gave $5^{-1}$ dilution. Similarly, dilutions were made up to $5^{-5}$. One $\mathrm{ml}$ aliquots of dilutions $10^{-1}$, $5^{-1}-5^{-5}$ were taken in six different Petri plates over which melted $\mathrm{T}_{3}$ agar medium (Travers et al. 1987) was poured and mixed clockwise and anti-clockwise directions. The plates were incubated (Hasthas Incubator, Hasthas Scientific Instruments, India) at $30{ }^{\circ} \mathrm{C}$ for $2-3$ days. From every soil sample, around 7-10 Bt-like colonies were chosen, sub-cultured as ribbon streak on $\mathrm{T}_{3}$ agar medium and incubated for $48 \mathrm{~h}$. To check the presence of protein crystals in the strains, culture smears were prepared, heat fixed and stained with the Coomassie Brilliant Blue stain (0.133\% Coomassie Brilliant Blue G250 in 50\% acetic acid). Then, the smears were washed softly in running tap water, blot dried with blotting paper and observed through bright-field microscope for the existence of crystalline inclusions. The strains which showed the presence of crystalline inclusions were selected as Bt. Single colony purification was performed on $\mathrm{T}_{3}$ agar medium and stored on $\mathrm{T}_{3}$ agar medium for further studies.

\section{Isolation of spore-crystal mixture from $B t$ strains}

A loopful of $B t$ culture from the $\mathrm{T}_{3}$ medium slant was inoculated into $5 \mathrm{ml}$ of $\mathrm{T}_{3}$ broth and incubated in a shaking incubator (Hasthas Shaking Incubator, Hasthas Scientific Instruments, India) maintained at $30{ }^{\circ} \mathrm{C}$ and $200 \mathrm{rpm}$. After overnight growth, $1 \%$ inoculum was added to $250-\mathrm{ml}$ flask containing $25 \mathrm{ml}$ of $\mathrm{T}_{3}$ medium and incubated at $30{ }^{\circ} \mathrm{C}$ in a shaking incubator maintained at $200 \mathrm{rpm}$ for nearly 48-60 h. The bacterial sporulation was monitored through bright-field microscope. When more than $90 \%$ of cells lysed, the sporulated broth culture was transferred to $4{ }^{\circ} \mathrm{C}$, at least half an hour before harvesting. The $\mathrm{T}_{3}$ broth containing spore-crystal mixture was centrifuged at $4{ }^{\circ} \mathrm{C}$. The pellet was resuspended in $25 \mathrm{ml}$ of ice-cold Tris-EDTA buffer [Tris $10 \mathrm{mM}$, EDTA $1 \mathrm{mM}, \mathrm{pH} 8.0$ with $1 \mathrm{mM}$ 
phenyl methyl sulphonyl fluoride (PMSF)] and washed once with $25 \mathrm{ml}$ of ice-cold $0.5 \mathrm{M} \mathrm{NaCl}$ centrifuged for $10 \mathrm{~min}$ followed by two washes with $25 \mathrm{ml}$ Tris-EDTA buffer with $0.5 \mathrm{mM}$ PMSF at the same speed and time. Finally, the spore-crystal pellet was suspended in $500 \mu \mathrm{l}$ of sterile distilled water containing $1 \mathrm{mM}$ PMSF and stored at $-20{ }^{\circ} \mathrm{C}$. All centrifugation steps were performed at the $5600 \mathrm{~g}$ speed at $4{ }^{\circ} \mathrm{C}$ (Superspin R-V/FM Plasto Crafts, Plasto Craft Scientific Pvt. Ltd, Mumbai, India).

\section{Cry protein electrophoresis}

Sodium dodecyl sulfate-polyacrylamide gel electrophoresis (SDS-PAGE) was carried out by the method of Laemmli (1970) using 10\% running and 4\% stacking gels. The gels were stained with $0.4 \%$ Coomassie Blue R250. The molecular mass of proteins was determined using a higher range protein molecular weight marker (myosin rabbit muscle $205 \mathrm{kDa}$, phosphorylase b $97.4 \mathrm{kDa}$, bovine serum albumin $65 \mathrm{kDa}$, ovalbumin $43 \mathrm{kDa}$ and carbonic anhydrase $29 \mathrm{kDa}$ ) obtained from $\mathrm{GeNei}^{\mathrm{TM}}$, Bengaluru, India.

\section{Insecticidal activity of Bacillus thuringiensis strains against Spodoptera litura}

A modified diet overlay assay method was employed to test the susceptibility of Spodoptera litura neonates to indigenous $B t$ strains. In each $1.8-\mathrm{ml}$ cryovial $\left(\operatorname{Tarson}^{\circledR} ; 1 \mathrm{~cm}\right.$ dia.), $1 \mathrm{ml}$ of artificial diet (Nagarkatti and Prakash 1974) was poured and $20 \mu \mathrm{l}$ of spore-crystal mixture (1:5 dilution) of indigenous $B t$ strains was smeared over the diet surfaces. Bt $4 \mathrm{D} 1$ served as positive control. Cryovials were air dried for 1.5-2 $\mathrm{h}$ in laminar airhood before infesting with the neonates of Spodoptera litura. One neonate was transferred into each vial and lids were half closed for aeration. The infested culture vials were kept at $27{ }^{\circ} \mathrm{C}$, $50 \% \mathrm{RH}$, and a photoperiod of 16-8 (LD) $\mathrm{h}$ for 7 days. Mortality was calculated after every $24 \mathrm{~h}$. Next different protein concentrations of spore-crystal mixtures $(1-5 \mu \mathrm{g})$ of potent $B t$ strains were used and results noted. The mean $50 \%$ lethal concentration was estimated by Probit analysis using statistical parameters.

\section{Distribution of cry genes in selected potential indigenous $B t$ strains}

Genomic DNA extracted using Sambrook and Russell's (2001) method from $B t$ strains was used for the amplification of cryl and cry 2 genes. For each polymerase chain reaction (PCR), $0.1 \mu \mathrm{g}$ of total genomic DNA and $1 \mu \mathrm{M}$ of each primer (Juarez-Perez et al. 1997; Ben-Dov et al. 1997) were mixed with $10 \mu \mathrm{l}$ of $2 \times$ PCR Master Mix $\left(\mathrm{GeNei}^{\mathrm{TM}}\right.$,
Bengaluru, India) consisting of dNTPs, Taq polymerase and PCR buffer. The final volume was made up to $20 \mu \mathrm{l}$ with sterile double distilled water. PCR amplification was performed in a thermal cycler (cyber cycler-P series PCR Peltier model p96+ USA).

\section{Identification of novel $\operatorname{cry} 2 A$ gene}

The full-length cry2A gene from $B t$ strain SWK1 was amplified using 2ARF ( $5^{\prime}$-ATGGTACCA TGAATAATGT ATTGAATAGTGGAA- $\left.3^{\prime}\right)$ and 2ARS (5'-GTTCTAGACT CAAACCTTAATA AAGTGGTG- $3^{\prime}$ ) and sequenced. The sequence was analyzed by PCR restriction fragment length polymorphism (in silico and in vitro). It was expressed in Escherichia coli BL21 (DE3) pLysS. Insecticidal activity of expressed Cry2Al1 toxin was performed against Lepidopteran (Spodoptera litura and Helicoverpa armigera) and Dipteran (Aedes aegypti, Culex quinquefasciatus and Anopheles stephensi larvae/pupae) insects.

\section{Results}

\section{Sample collection and bacterial isolation}

A total of 159 Kashmir samples including soil, leaves and spider webs were collected from the Himalayan valley Kashmir. Out of 159 samples of Kashmir valley, 68 Bt strains (Table 1) were obtained based on the presence of protein crystals and $\mathrm{T}_{3}$ as a selective medium. The number of $B t$ strains was isolated higher from the soil samples collected from Bandipore with $0.075 B t$ index and the lowest number was isolated from Baramulla samples with $0.028 \mathrm{Bt}$ index. The strains were further purified as a single colony and were maintained at $4{ }^{\circ} \mathrm{C}$.

\section{Crystal morphologies}

In $68 \mathrm{Bt}$ strains, different types of crystal proteins morphologies, viz., bipyramidal crystals, spherical crystals, cuboidal crystals, spore attached crystals, rod-shaped crystals (Online resource 2) were observed under brightfield microscope (Magnus MLXi, Olympus, Japan). A single type of crystal morphology was observed in $73.92 \%$ of the strains and more than one type of crystal morphology was present in other $26.08 \%$ of the strains. Most of the isolated strains were found to possess spherical crystals. In the present study, crystal morphology ranking was spherical $\quad(69.11 \%)>$ spore attached $(8.82 \%)>\operatorname{rod}$ $(5.88 \%)=$ bipyramidal $(5.88 \%)>$ spherical plus rod $(4.41 \%)>$ spherical plus bipyramidal $(2.94 \%)=$ cuboidal (2.94\%) among the strains from Kashmir. 
Table 1 Isolation of B. thuringiensis from samples of Kashmir valley

\begin{tabular}{|c|c|c|c|c|c|c|c|c|}
\hline \multirow[t]{2}{*}{ S. no. } & \multirow[t]{2}{*}{ Area } & \multicolumn{3}{|c|}{ Number of samples } & \multicolumn{3}{|c|}{ Number of colonies } & \multirow[t]{2}{*}{ Bt index } \\
\hline & & Examined & Number of $B t$ positive ${ }^{a}$ & $\%$ & Examined & Number of $B t$ positive $^{a}$ & $\%$ & \\
\hline 1. & Anantnag & 17 & 04 & 23.52 & 168 & 6 & 3.57 & 0.036 \\
\hline 2. & Bandipore & 16 & 05 & 31.25 & 120 & 9 & 7.50 & 0.075 \\
\hline 3. & Baramulla & 20 & 04 & 20.00 & 180 & 5 & 2.77 & 0.028 \\
\hline 4. & Budgam & 19 & 06 & 31.57 & 157 & 8 & 5.09 & 0.051 \\
\hline 5. & Ganderbal & 13 & 03 & 23.07 & 135 & 5 & 3.70 & 0.037 \\
\hline 6. & Kulgam & 16 & 02 & 12.50 & 128 & 7 & 5.46 & 0.055 \\
\hline 7. & Kupwara & 14 & 06 & 42.85 & 156 & 9 & 5.76 & 0.058 \\
\hline 8. & Pulwama & 12 & 05 & 41.66 & 144 & 6 & 4.16 & 0.042 \\
\hline 9. & Shopian & 16 & 07 & 43.75 & 120 & 8 & 6.66 & 0.067 \\
\hline 10. & Srinagar & 16 & 04 & 25.00 & 139 & 5 & 3.59 & 0.036 \\
\hline Total & & 159 & 46 & 28.93 & 1447 & 68 & 4.60 & 0.047 \\
\hline
\end{tabular}

${ }^{\mathrm{a}}$ Crystalliferous bacterium

\section{SDS-polyacrylamide gel electrophoresis (SDS-PAGE)}

A total of 23 strains were studied for crystal protein profile(s) by SDS-PAGE. The time for parasporal crystal formation and completion of sporulation was checked always before isolation. Bt 4D1 was used as a positive control. SDS-PAGE investigation of the spore-crystal mixture demonstrated that $B t$ strains contained proteins of various molecular weights, viz., 150, 135, 130, 105, 98, 95, 91, 90, 70, 65, 45, 42, 34, $28 \mathrm{kDa}$ (Fig. 1). Among the selected $23 B t$ strains, 05 strains $(21.74 \%)$ were found to produce single protein band only and $18 \mathrm{Bt}$ strains $(78.26 \%)$ showed more than one protein band with different molecular weights. Most of the indigenous $B t$ strains $(73.92 \%)$ produced proteins in the range of 60 to $70 \mathrm{kDa}$.
The 130 to $135 \mathrm{kDa}$ proteins were next predominant proteins present in the $B t$ strains $(43.47 \%)$ from different environments. Five strains $(21.74 \%)$ were found to have proteins in the $\sim 30-35 \mathrm{kDa}$ range. Two strains $(8.7 \%)$ out of $23 \mathrm{Bt}$ strains produced proteins of $\sim 28 \mathrm{kDa}$. This diversity in proteins indicated that $B t$ strains may have diverse cry genes and insecticidal activities. Around 135 and $75 \mathrm{kDa}$ proteins suggest the presence of genes related to cry 1 or cry 4 and cry 2 or cry 3 , respectively.

\section{Insecticidal activity}

Primary screening of insecticidal activity of newly isolated 68 indigenous $B t$ strains with $20 \mu \mathrm{l}$ of spore crystal-protein mixtures (1:5 dilutions) against the Spodoptera litura revealed only $19(27.94 \%)$ strains were active. When
Fig. 1 SDS-PAGE analysis of spore crystal mixture of indigenous $B t$ strains

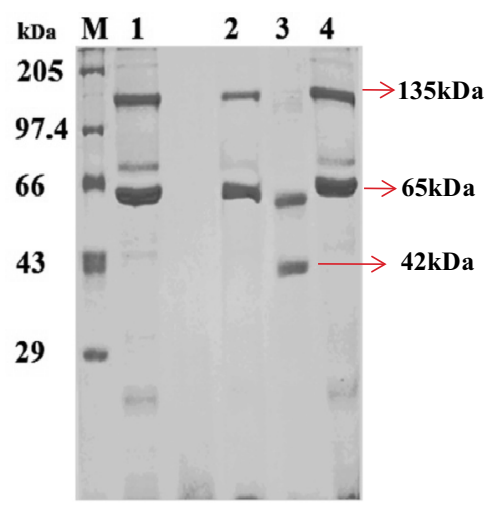

Lane M: Protein molecular marker

Lane 1: Bacillus thuringiensis subsp. kurstaki HD1

Lane 2: Bacillus thuringiensis strain KS2-6

Lane 3: Bacillus thuringiensis strain KNG1

Lane 4: Bacillus thuringiensis strain PAH5

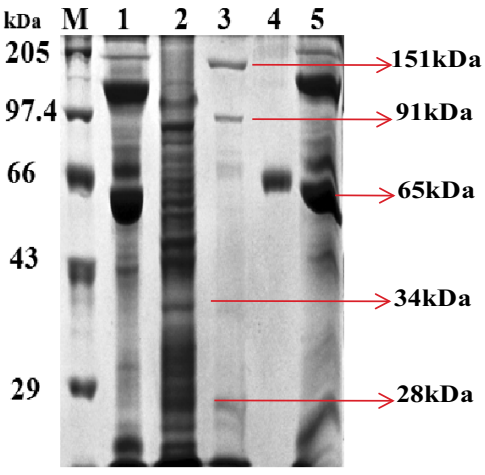

Lane M: Protein molecular marker

Lane 1: Bacillus thuringiensis subsp. kurstaki HD1

Lane 2: Bacillus thuringiensis strain MS1-4

Lane 3: Bacillus thuringiensis strain 2PAH5

Lane 4: Bacillus thuringiensis strain YMK11

Lane 5: Bacillus thuringiensis strain QZ-19 
Table 2 Probit regression analysis of mortality data of Spodoptera litura larvae treated with spore crystal mixture of indigenous Bacillus thuringiensis by surface-diet method

\begin{tabular}{|c|c|c|c|c|c|}
\hline Serial number & Bt strain & $\mathrm{LC}_{50}(\mu \mathrm{g} / \mathrm{ml})$ & $95 \%$ confidential limits of concentration & Slope \pm SE & $\chi^{2}$ \\
\hline 1 & $4 \mathrm{D} 1$ & 1.912 & $1.820-2.010$ & $1.643 \pm 0.0796$ & 1.454 \\
\hline 2 & SWK1 & 1.978 & $1.914-2.045$ & $1.523 \pm 0.0457$ & 0.138 \\
\hline 3 & KS2-3 & 2.047 & $1.942-2.158$ & $1.719 \pm 0.0881$ & 0.534 \\
\hline 4 & $2 \mathrm{M}-6$ & 2.199 & $2.027-2.296$ & $1.619 \pm 0.1028$ & 1.354 \\
\hline 5 & KS2-6 & 2.303 & $2.213-2.398$ & $1.606 \pm 0.0546$ & 0.498 \\
\hline 6 & QZ-19 & 2.853 & $2.708-3.006$ & $1.831 \pm 0.1076$ & 2.287 \\
\hline 7 & KNG-2 & 3.585 & $3.392-3.788$ & $1.694 \pm 0.0990$ & 1.628 \\
\hline 08 & PAH-5 & 4.279 & $4.062-4.509$ & $1.831 \pm 0.1076$ & 2.287 \\
\hline 09 & BAD & 4.474 & $4.256-4.703$ & $1.551 \pm 0.0749$ & 2.638 \\
\hline 10 & MS1-14 & 5.695 & $5.231-6.200$ & $1.497 \pm 0.1227$ & 1.148 \\
\hline 11 & YMK-7 & 5.771 & $5.328-6.252$ & $1.544 \pm 0.1211$ & 1.537 \\
\hline 12 & YMK-11 & 6.500 & $5.103-6.397$ & $1.479 \pm 0.0787$ & 0.799 \\
\hline 13 & $3 \mathrm{M} 13$ & 6.193 & $5.633-6.718$ & $1.383 \pm 0.1063$ & 1.658 \\
\hline 14 & 2PAH20 & 6.247 & $5.841-6.682$ & $1.365 \pm 0.0785$ & 1.341 \\
\hline 15 & KNG-1 & 7.605 & $7.103-8.142$ & $1.590 \pm 0.0886$ & 0.657 \\
\hline 16 & QZ-22 & 7.850 & $7.680-8.448$ & $1.447 \pm 0.0889$ & 0.465 \\
\hline 17 & 2РAH-4 & 8.118 & $7.585-8.689$ & $1.375 \pm 0.0649$ & 0.248 \\
\hline 18 & $2 \mathrm{M}-7$ & 7.908 & $7.440-8.406$ & $1.510 \pm 0.0699$ & 0.398 \\
\hline 19 & $2 \mathrm{M} 2$ & 8.996 & $8.437-9.592$ & $1.359 \pm 0.0515$ & 0.210 \\
\hline 20 & YMK-6 & 9.596 & $9.000-10.23$ & $1.359 \pm 0.0515$ & 0.210 \\
\hline
\end{tabular}

different protein concentrations of these $B t$ strains were used, it was found that $B t$ strain SWK1 has the highest mortality which was comparable to positive control $B t$ 4D1. It has shown an $\mathrm{LC}_{50}$ of $1.978 \mu \mathrm{g} / \mathrm{ml}$ followed by KS2-3, 2M-6, KS2-6, QZ-19, KNG-2 with an $\mathrm{LC}_{50}$ of $2.047,2.199,2.303,2.853,3.585 \mu \mathrm{g} / \mathrm{ml}$, respectively. The results of probit regression analysis of dose-response mortality data for the bioassays of proteins of spore-crystal mixture of indigenous Bt strains are summarized in Table 2. The mortality data fitted the probit model that was confirmed by the Chi-square goodness-of-fit test.

\section{Distribution of lepidopteran-active cry genes in selected indigenous $B t$ strains}

PCR for three types of lepidopteran-active genes in 06 potential $B t$ strains revealed their presence in most of the strains. The most abundant cry gene was cryl-type gene. All the six selected strains (100\%) showed the presence of cryl type genes ( 1500 bp) (Fig. 2$)$ and cry $2 A a$ type genes ( $498 \mathrm{bp}$ ) (Fig. 3). It was followed by cry $2 A b$. Out of $06 \mathrm{Bt}$ strains, $05 \mathrm{Bt}$ strains $(90 \%)$ gave positive results for $c r y 2 A b$ gene with a PCR product of expected size at around $500 \mathrm{bp}$ with specific primers (Fig. 4). Five $B t$ strains, viz., SWK1, KS2-3, 2M-6, KS2-6, QZ-19 contained all $c r y l$, cry $2 A a$ and $c r y 2 A b$ genes like $B t$ strain

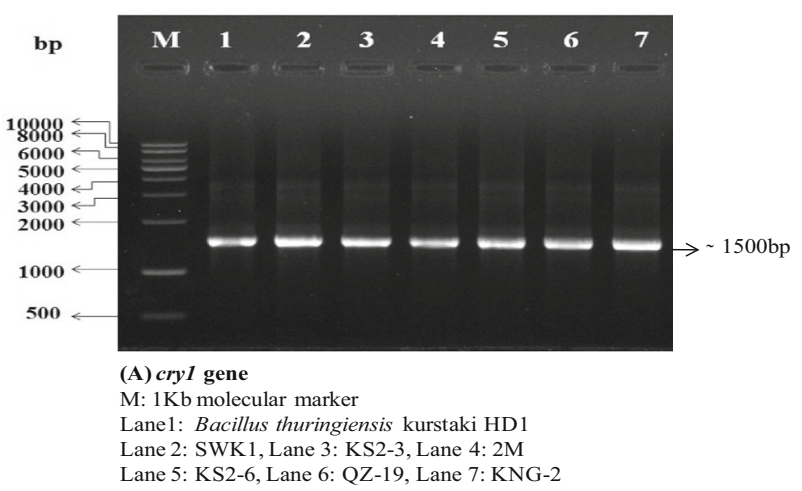

Fig. 2 Agarose gel (0.8\%) electrophoresis of PCR products of cryl gene from selected active $B t$ strains

4D1. All these five strains were found to have proteins of 135 and $65 \mathrm{kDa}$. Further, analysis of full-length cry $2 \mathrm{~A}$ genes revealed the presence of a new cry $2 A$ holotype gene in Bacillus thuringiensis strain SWK1 which was named as cry $2 A l 1$ by $B t$ toxin nomenclature committee (Crickmore et al. 2016; http://www.btnomenclature.info). This new cry $2 A$ holotype could be expressed as $\sim 65 \mathrm{kDa}$ protein in E. coli BL21 (DE3) pLysS strain under the control of T7 promoter induced with IPTG. Expressed Cry2Al1 protein was found highly toxic to neonates of Spodoptera litura

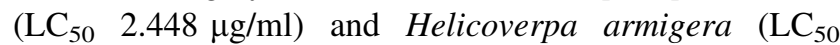




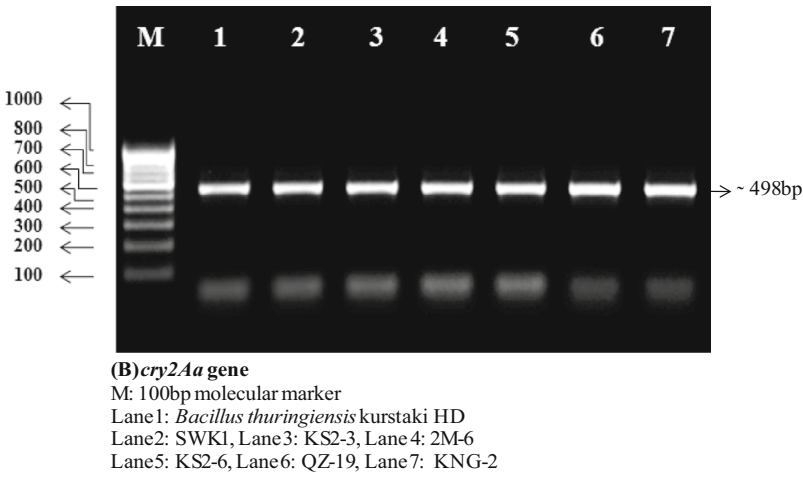

Fig. 3 Agarose gel electrophoresis (1.5\%) of PCR products of cry $2 A a$-specific genes from some selected active $B t$ strains

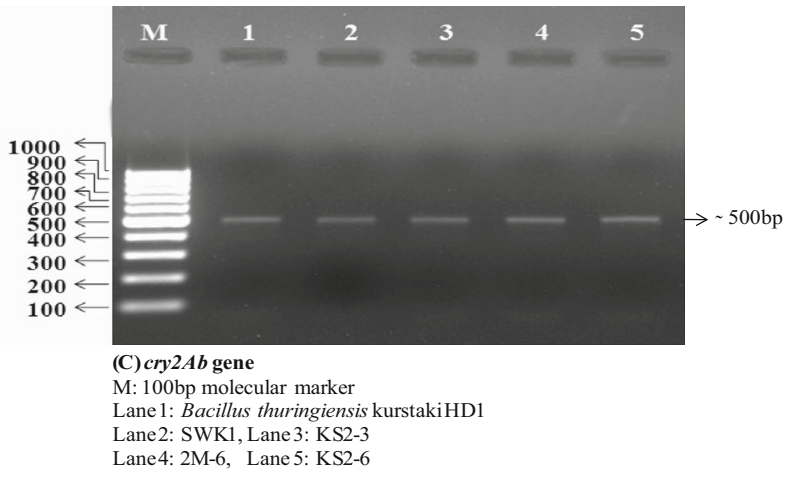

Fig. 4 Agarose gel electrophoresis (1.5\%) of PCR products of $c r y 2 A b$-specific genes in some selected active $B t$ strains

$3.374 \mu \mathrm{g} / \mathrm{ml}$ ) (Reyaz and Indra Arulselvi 2016). We could not detect any mortality with Cry2Al1 protein $(100 \mu \mathrm{g} / \mathrm{ml})$ in any of the epidemiological disease-causing vectors: Aedes aegypti, Culex quinquefasciatus and Anopheles stephensi larvae/pupae at $28 \pm 2{ }^{\circ} \mathrm{C}$ and 75 to $85 \%$ relative humidity under a photoperiod of $14 \mathrm{~L}: 10 \mathrm{D}$ in our laboratory.

\section{Discussion}

\section{Isolation of $B t$ strains}

B. thuringiensis strains have been found worldwide from diverse habitats, including the micro flora of soil and aquatic habitats (Martin and Travers 1989; Martinez and Caballero 2002; Uribe et al. 2003, Unalmis et al. 2015), phylloplane (Mizuki et al. 1999), freshwater (Ichimatsu et al. 2000), marine sediments (Maeda et al. 2000), freeliving animals (Swiecicka et al. 2002), bank voles (Swiecicka and De Vos 2003) and other environment (Meadows et al. 1992). This bacterium is widely distributed in five continents (Bernhard et al. 1997), ranging from tropics (Hastowo et al. 1992) to the high altitude (Landen et al. 1994). B. thuringiensis strains were isolated from different agro-climatic regions of India (Prabagaran et al. 2002). In the present study, Bt strains were isolated from soil, leaf and spider web samples collected at Kashmir valley situated in the northwestern tip of the Himalayan biodiversity hotspot. A total of 159 samples were collected from the Himalayan valley Kashmir. From 159 samples of Kashmir valley, $68 \mathrm{Bt}$ strains were isolated. Goudar et al. (2012) isolated and characterized the $B t$ strains from Western Ghat regions of Uttara Kannada district of Karnataka. They collected a total of 204 samples comprising 157 soil samples, 38 leaves, 5 leaf litter and 4 compost samples and isolated $44 \mathrm{Bt}$ strains. Out of these 44 strains, 27 were obtained from soil samples, 12 from leaf sample, one from leaf litter and four strains from compost samples. Shishir et al. (2014) reported an isolation of $317 \mathrm{Bt}$ strains from 231 samples collected from 26 districts encompassing 6 different regions of Bangladesh. Initial identification of $B t$ is mostly based on the presence of crystalline inclusions. The bright-field microscopy is more useful than phase contrast microscopy for high-throughput evaluation of stained bacterial colonies for the presence of crystals and also for identification of small crystals (Ammons et al. 2002). In our study, 68 of the 1447-stained bacterial colonies observed through bright-field microscopy showed the presence of crystalline inclusions and were identified as Bt. Ramalakshmi and Udayasuriyan (2010), observed 6629-stained bacterial and found 316 bearing crystalline inclusions through bright-field microscopy and considered them as Bt. Different types of crystalline inclusion morphologies, viz., bipyramidal, spherical, cuboidal, spore attached and rod-shaped were observed in our 68 indigenous $B t$ strains under bright-field microscope. Single type of Cry protein crystals was observed in $73.92 \%$ of the strains and more than one type of crystal was present in other $26.08 \%$ of the strains. Most of the isolated strains were found to possess spherical crystals and the crystal morphology ranking was spherical $(69.11 \%)>$ spore attached $(8.82 \%)>\operatorname{rod}(5.88 \%)=\operatorname{bipyramidal}(5.88 \%)>$ spherical plus rod $(4.41 \%)>$ spherical plus bipyramidal $(2.94 \%)=$ cuboidal $(2.94 \%)$ among the Kashmir strains. These findings varied from the previous reports (Bernhard et al. 1997; Martin and Travers 1989; Ramalakshmi and Udayasuriyan 2010) wherein strains with bipyramidal crystals or cuboidal crystal were predominant (46\%). Because of the diversity in climatic conditions, the sporulation stage of $B$. thuringiensis strains and the presence of cry genes may vary (Attathoma et al. 1995). Variations observed in the morphology of crystalline inclusions in our $B t$ strains suggested the presence of diversity in these strains from Kashmir. Bt index in our Kashmir samples ranged from 0.028 to 0.075 with an overall $B t$ index of 
0.047. In earlier reports varying values of $B t$ index were frequently reported in several studies which ranged from 0.009 to 0.380 in soil samples of Krabi province (Thaphan et al. 2008), 0.034 to 0.055 in samples of Western Ghats, India (Ramalakshmi and Udayasuriyan 2010) and 0.2 to 0.5 in sample from New Zealand (Chilcott and Wigley 1993). In other earlier reports frequency for isolation of $B t$ from soil samples varied, ranging from 3 to $85 \%$ (Wang et al. 2003). Recently Shishir et al. (2014) reported $0.86 B t$ index in their samples from Bangladesh. Vilas-Böas and Manoel (2004) suggested the $B t$ index may be an outcome of the biotic environmental factor, e.g., the vegetal top, the type of insect commonly found in the area, or microorganism in the soil, besides, abiotic factors such as the nutrient availability, texture, $\mathrm{pH}$, temperature and humidity. On these grounds, they circumvent comparing their result with those of other authors, as they considered that the procedures of collection of sample, storage, processing, and identification of the bacteria were influenced by the experience of the working group and this may influence the result.

\section{Protein profiling}

Grouping of $B t$ strains according to crystal protein(s) profile studied by SDS-PAGE gives a preface for the presence of diversity in cry genes. Therefore, analysis of crystal proteins(s) profile could be useful to predict the presence of cry genes. The 130-138 kDa lepidopteran-active Cry proteins are encoded by cry 1 genes. The Cry 2 and Cry 3 proteins are 65 and $70 \mathrm{kDa}$, respectively. The dipteran active, Cry 4 and Cry10 or Cry11 proteins are 135 and $80 \mathrm{kDa}$, respectively (Chambers et al. 1991). We in this study performed SDS-PAGE analysis of 23 selected $B t$ strains. Among these, 05 strains (21.74\%) were found to produce one protein band only and $18 \mathrm{Bt}$ strains (78.26\%) showed more than one protein band with different molecular weights. Most of the indigenous Bt strains (73.92\%) produced proteins in the range of 60 to $70 \mathrm{kDa}$. The 130 to $135 \mathrm{kDa}$ proteins were next principal proteins present in the $B t$ strains $(43.47 \%)$ from different environments. Five strains $(21.74 \%)$ were found to have proteins in the $\sim 30-35 \mathrm{kDa}$ range. Two strains $(8.7 \%)$ out of $23 \mathrm{Bt}$ strains produced proteins of $\sim 28 \mathrm{kDa}$. Ramalakshmi and Udayasuriyan (2010) reported earlier that out of their $70 \mathrm{Bt}$ strains analyzed by SDS-PAGE, 17 strains (24.2\%) exhibited two major polypeptide bands with molecular weights in the range of 135 and $65 \mathrm{kDa}$. Whereas, crystal protein(s) of $135,95,65,43,30 \mathrm{kDa}$ were observed in their 15 (21.4\%), 12 (17.1\%), 7 (10\%), 4 (5.7\%), and 7 (10\%) Bt strains, respectively. The analyses of $146 B t$ strains on SDS-PAGE by Arrieta and Espinoza (2006) showed diverse electrophoretic patterns with molecular weight of the Cry proteins in the range of $20-160 \mathrm{kDa}$ (e.g., $B t$ CIBCM-279: 50, 40, $20 \mathrm{kDa}$; Bt CIBCM-1: 65, 50, $45 \mathrm{kDa}$; Bt CIBCM-5: 125, 70, $50 \mathrm{kDa}$; $B t$ CIBCM-355: 160, 95, 65, $33 \mathrm{kDa}$ ). Liu et al. (2009) isolated a novel strain of Bacillus thuringiensis Bt11, from soil samples in China which revealed several polypeptides ranging from 20 to $130 \mathrm{kDa}$ during SDS-polyacrylamide gel electrophoresis of which the 35,80 , and $130 \mathrm{kDa}$ proteins were the major components. Zheng et al. (2010) reported a Bacillus thuringiensis isolate JF19-2 from the soil samples of Sichuan Basin in western China which contained a bipyramidal crystal harboring one insecticidal crystal protein (about $70 \mathrm{kDa}$ ). The diversity in proteins of our $B t$ strains indicated these may have diverse cry genes and insecticidal activities. Gough et al. (2005) studied Bacillus thuringiensis strains collected from various Australian soil samples which produced crystals containing 130 and $28 \mathrm{kDa}$ proteins. These strains were highly toxic to feeding larvae of sheep blowfly (Lucilia cuprina). Ibarra et al. (2003) reported Bacillus thuringiensis strains (LBIT315, LBIT320, LBIT348, and IB604) from Latin America which are highly toxic against different mosquito species with major proteins of 130,70 , and $28 \mathrm{kDa}$ similar to B. thuringiensis subsp. israelensis. They also reported $B t$ strain 147-8906 which had four different protein bands of $100,75,65$, and $26 \mathrm{kDa}$. Earlier some investigators have reported a correlation between crystal morphology and type of proteins produced. The Cry1 (130-138) kDa lepidopteran-active proteins formed bipyramidal crystalline inclusions. The dipteran active, Cry 4 and Cry 10 or Cry 11 proteins of 135 and $80 \mathrm{kDa}$ sizes, respectively, formed spherical inclusions (Chambers et al. 1991). But in the present study, we could not establish a correlation between crystal morphology, molecular weight and a number of proteins produced by a $B t$ strain. Our results are in agreement with Arrieta and Espinoza (2006) who also reported there was no correlation between the morphology of the inclusion body, the molecular weight of the $\delta$-endotoxins and the number of Cry proteins produced. They reported a strain from Braulio Carrillo with pleomorphic crystals having proteins of 60,70 and $100 \mathrm{kDa}$, while another strain with the same crystal morphology isolated from Santa Rosa contained a single polypeptide of $70 \mathrm{kDa}$.

\section{Bioinsecticidal activity against Spodoptera litura}

Spodoptera litura (Lepidoptera: Noctuidae) has surfaced as a key polyphagous pest in the recent past (Brown and Dewhurst 1975; Holloway 1989). This pest has been reported to attack a broad array of crops (about 40 species of plants) in Indian sub-continent (Chari and Patel 1983). Because of their ability to inflict serious economic damage to the crops in India, this insect pest has been subjected to

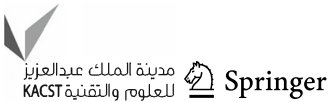


heavy doses of insecticidal treatments. Indiscriminate and non-judicious use of insecticides has resulted in the development of resistance in this pest to as many as 20 different active ingredients of insecticides (Whalon et al. 2007). It is known that insects could be susceptible to different Cry toxins (Liao et al. 2002; Sauka et al. 2007). Protein profiling of selected indigenous strains confers that our indigenous strains have different Cry toxins which could be susceptible to various types of insects belonging to different orders. In this study, we tested the susceptibility of our Bt strains towards Spodoptera litura using an artificial diet. Modified diet overlay assay method was used by Liu et al. (2009) to test the susceptibility of Helicoverpa armigera and Spodoptera exigua neonates to Bt11 and showed $100 \%$ mortality of these two pests at the concentration of $5.9 \times 10^{7}$ spores $/ \mathrm{ml}$. Thaphan et al. (2008) screened toxicities of various $B t$ strains primarily on second-instar larvae of Plutella xylostella and on neonate larvae of Spodoptera litura and $S$. exigua with highly concentrated spore-crystal suspension and observed mortality after 3 days. Preliminary insect bioassay carried out in vitro by Reddy et al. (2013) with crude protein extracted from DOR $B t-1$ isolate had shown that the strain was effective against Spodoptera litura, $H$. armigera and $A$. janata insect pest. We performed the primary screening of insecticidal activity of newly isolated 68 indigenous $B t$ strains with diluted $20 \mu \mathrm{l}(1: 5)$ of spore crystal-proteins mixture against the Spodoptera litura pest. Among these, $19(27.94 \%)$ strains were found active with different toxicities levels. Whitlock et al. (1991) have reported a narrow range of pathogenicity of $B$. thuringiensis products against S. litura. According to Federici (1999), B. thuringiensis products were not always effective in controlling certain noctuid pests, especially the species of Spodoptera, viz., $S$. litura, S. frugiperda (Smith) and S. littoralis (Boisduval). Prabagaran et al. (2002) reported that out of 18 Bt strains subjected to single-dose assays against second-instar larvae of $S$. litura, five $B t$ strains $(27.78 \%$ ) had been found to be effective in killing at least $50 \%$ of the laboratory-reared insect population. Hire et al. (2009) reported a cry $2 \mathrm{Aa} 14$ from an indigenous Bt strain HD-550 toxic to lepidopteran and dipteran insects. The expressed protein had shown toxicity to Spodoptera litura and Culex quinquefasciatus. The $B t$ isolate 01-CHI-01 obtained from cadavers of a silkworm, Bombyx mori L. caused $71.3 \%$ mortality of Spodoptera litura by Leaf dip method (Manimegalai et al. 2005). In our study, $08 \mathrm{Bt}$ strains have shown above $60 \%$ mortality of Spodoptera litura by surface diet method with diluted (1:5) spore-crystal mixture. Similarly, preliminary assays performed with spore-crystal mixture by Patel et al. (2009) revealed that all their $07 \mathrm{Bt}$ strains (100\%) tested against second-instar larvae of $H$. armigera were toxic with varying percentage of mortality ranging from 20 to $80 \%$ after $48 \mathrm{~h}$ of infestation. Bioassay study conducted by Goudar et al. (2012) with 44 strains against the third instar larvae of Plutella xylostella resulted in the cumulative mortality which ranged from 17 to $100 \%$ after $72 \mathrm{~h}$ of exposure. The insecticidal toxicity of 56 native $B$. thuringiensis strains investigated against first instar larva of E. kuehniella showed $80 \%$ of the strains had varying degrees of toxicity, whereas $20 \%$ of the strains were not toxic. About half of the native strains (44.6\%) caused mortality between 10 and $30 \%$. In addition, the mortality range of 13 strains was lower than $10 \%$ and that of 6 strains was moderate (30-50\%). However, only one strain $(85 \mathrm{PPb})$ showed very high toxicity ( $84 \%$ mortality) (Apaydin et al. 2008).

\section{Dose mortality response proteins of spore-crystal mixture of indigenous $B t$ strains}

When different proteins concentrations of some of our high-responsive $B t$ strains were used, $B t$ strain SWK1 had shown the highest mortality which was comparable to positive control $B t 4 \mathrm{D} 1$. It had shown an $\mathrm{LC}_{50}$ of $1.978 \mu \mathrm{g} /$ $\mathrm{ml}$ with an LT50 of $38.76 \mathrm{~h}$. It was followed by KS2-3, 2M-6, KS2-6, QZ-19, KNG-2, PAH-5, BAD with an $\mathrm{LC}_{50}$ of $2.047,2.199,2.303,2.853,3.585,4.279,4.474 \mu \mathrm{g} / \mathrm{ml}$, respectively, and LT50 of 45.68, 42.36, 43.14, 50.50, $52.91,57.58,52.48 \mathrm{~h}$, respectively. The mortality data fitted the probit model that was confirmed by the Chisquare goodness-of-fit test. In earlier reports by Whitlock et al. (1991), two strains had shown more activity than $B t$ 4D1 against Spodoptera litura. However, in our study none of the strains showed more activity than $B t 4 \mathrm{D} 1$ against this pest. Prabagaran et al. (2002) reported that LT50 values of five $B t$ strains, viz., PBT-782, PBT-372, PBT-574, PBT801, and PBT-716 were 25.46, 36.81, 48.18, 50.35 and $73.53 \mathrm{~h}$, respectively. They correlated these LT50 values and efficacy in controlling $S$. litura with the presence or absence of a specific cry subgroup gene (crylAal, crylAbl, crylAcl, crylCal, crylDal) in different $B$. thuringiensis strains.

\section{Detection of Lepidopteran-active cry genes in new $B t$ strains by PCR}

Lepidopteran-specific toxic proteins are produced by cry genes (Crickmore et al. 1998). PCR for three types of lepidopteran-active genes in 06 potential $B t$ strains revealed their presence in most of the strains. All the six selected strains $(100 \%)$ showed the presence of cryl type genes (1500 bp) and cry2Aa type genes (498 bp). It was followed by $c r y 2 A b$. Out of $06 B t$ strains, $05 B t$ strains (90\%) gave positive results for $c r y 2 A b$ gene with a PCR product of expected size at around $500 \mathrm{bp}$ with specific 
primers. Five $B t$ strains, viz., SWK1, KS2-3, 2M-6, KS2-6, QZ-19 contained all cryl, cry2A $a$ and $c r y 2 A b$ genes like $B t$ strain 4D1. All these five strains were found to have proteins of 135 and $65 \mathrm{kDa}$. Patel et al. (2013) reported the presence of cryl, cry2, cry3, cry 7, cry8, cry 4, cry5, cry 12 , cry 14, cry 21, cry 11, cry 13 and cyt 1 genes from Bt strains isolated from various regions of India by PCR amplification. In their investigation, the cryl gene was also the most abundant gene present. Prabagaran et al. (2002) reported the presence of cryl genes (crylAal, crylAbl, crylAcl, crylCal, crylDal) in different indigenous $B$. thuringiensis strains potentially active against Spodoptera litura. Recently, the abundance of cry genes in the $B t$ strains from Bangladesh was screened by Shishir et al. (2014) and reported cryl gene as the most abundant with (30.8\%) followed by cry $2(25.5 \%)$, cry3 $(22.2 \%)$, and cry9 $(7.2 \%)$ genes. Reddy et al. (2013) have reported a novel cryl gene from Bt-1 DOR isolate effective against Spodoptera litura and other lepidopteran pests. Further, in our studies we found $c r y 2 A a$ genes more in abundance than $c r y 2 A b$. Our results differed from the results of Shu et al. (2013) wherein they reported an abundance of $c r y 2 A b$ genes more compared to $c r y 2 A a$ by pooled clone method. This difference or variation in the cry $2 A$ sub type's content may be due to the fact that we selected the Spodoptera litura active $B t$ strains alone for PCR amplification. Five $B t$ strains, viz., SWK1, KS2-3, 2M-6, KS2-6, QZ-19 contained all cry1, $c r y 2 A a$ and $c r y 2 A b$ genes like $B t$ strain $4 \mathrm{D} 1$. All these five strains were found to have proteins of $\sim 135$ and $\sim 65 \mathrm{kDa}$. Porcar et al. (2000) reported that Cry1C, Cry1D, Cry1E, Cry1F and Cry9C proteins were highly toxic towards Spodoptera species. Earlier Tabashnik et al. (1994) reported that Cry1Aa, Cry1Ab, Cry1Ac, Cry1B, Cry1C, Cry1F and Cry2A were highly toxic to P. xylostella. Song et al. (2003) reported that Cry1I was toxic to P. xylostella, Ostrinia furnacalis and Leguminivora glycinivorella. Xue et al. (2008) reported that Cry1Aa was highly toxic to Ostrinia furnacalis, Helicoverpa armigera, Chilo suppressalis, and Plutella xylostella. Shu et al. (2013) developed an improved PCR-Restriction Fragment Length Polymorphism (RFLP) method for the identification of cryl-type genes which could efficiently identify single and clustered cryl-type genes. Among the evaluated cryl-type genes in their novel strain collections of B. thuringiensis, they identified four novel genes, crylAi, crylBb, crylJa, and crylLa. In our study, PCR-RFLP analysis of fulllength cry $2 \mathrm{~A}$ genes revealed the presence of a novel cry $2 \mathrm{~A}$ gene in Bacillus thuringiensis SWK1 strain which was named as cry $2 \mathrm{All}$ by $\mathrm{Bt}$ toxin nomenclature committee. Expressed Cry2Al1 protein showed promising larvicidal activity against $S$. litura $\left(\mathrm{LC}_{50}=2.448 \mu \mathrm{g} / \mathrm{ml}\right)$ and $H$. armigera $\left(\mathrm{LC}_{50}=3.374 \mu \mathrm{g} / \mathrm{ml}\right)$ (Reyaz and Indra Arulselvi 2016). However, it did not show any activity against the epidemiological disease-causing vectors: Aedes aegypti, Culex quinquefasciatus and Anopheles stephensi larvae/pupae at $100 \mu \mathrm{g} / \mathrm{ml}$. Zheng et al. (2010) reported a novel haplotype cry2A-type gene (Cry2Ag1 protein) by PCR-RFLP method with insecticidal activity against $A$. aegypti (Diptera), P. xylostella (Lepidoptera), and $H$. armigera (Lepidoptera). It had shown $\mathrm{LC}_{50}$ of $2.541 \mu \mathrm{g} / \mathrm{ml}$ against $A$. aegypti, $\mathrm{LC}_{50}$ of $9.745 \mu \mathrm{g} / \mathrm{ml}$ against $H$. armigera and $\mathrm{LC}_{50}$ of $23.478 \mu \mathrm{g} / \mathrm{ml}$ against $P$. xylostella. Hire et al. (2009) reported Cry2Aa14 protein highly toxic to $S$. litura and $H$. armigera with $\mathrm{LC}_{50}$ of $694 \mathrm{ng} / \mathrm{cm}^{2}$ and $\mathrm{LC}_{50}$ value of $122 \mathrm{ng} / \mathrm{cm}^{3}$, respectively. Lenin et al. (2001) reported a Cry2Aa protein which had shown $71.4 \%$ mortality and severe (81-99\%) inhibition in larval growth of $H$. armigera on the seventh day at the concentration of $2.3 \mu \mathrm{g} /$ $\mu \mathrm{l}$. Besides, in transgenic cotton plants Cry2Ab/Cry2Ae has been incorporated in addition to the Cry1A as a resistance managing mechanism (Christou et al. 2006; https://www.isaaa.org). In conclusion, even though many $B t$ Cry toxins have already been isolated and shown to be an important means for insect control, particularly with the development of transgenic plants, the discovery of additional novel $B t$ strains with novel cry genes continues to harness the further improvements of Cry proteins as competitive and successful biological insecticides. Our results advocate that the cry $2 A l 1$ gene is not merely a novel resource in the field of research into insecticidal crystal genes, but it may also act as a prospective alternative toxin to resolve some of the impending problems associated with insect resistance. These results also support that our indigenous $B t$ strains need to be evaluated for other Cry toxins which could be novel and interesting to $B t$ technology for crop protection. On the whole, our results are of significance because $S$. litura is known to be tolerant to the majority of the known $\delta$-endotoxins (Singh et al. 2004).

Acknowledgements We would like to thank Dr. Daniel R. Zeigler (Ph.D.), director of Bacillus Genetic Stock Center (Columbus, Ohio) for providing $B t$ strains for reference purpose. We are grateful to the Director of National Bureau of Agricultural Insect Resources (NBAIR) for providing S. litura and H. armigera. We also extend our thanks to the Director of 'Centre for Research in Medical Entomology (CRME)' Madurai, Tamil Nadu for providing mosquito cultures: $C$. quinquefasciatus, A. stephensi and A. aegypti.

\section{Compliance with ethical standards}

Conflict of interest The authors declare that there is no conflict of interest regarding the publication of this paper.

\section{References}

Ammons D, Rampersad J, Khan A (2002) Usefulness of staining parasporal bodies when screening for Bacillus thuringiensis. J Invertebr Pathol 79:203-204 
Apaydin O, Cinar C, Turanli F, Harsa S, Gunes H (2008) Identification and bioactivity of native strains of Bacillus thuringiensis from grain-related habitats in Turkey. Biol Control 45:21-28

Arrieta G, Espinoza AM (2006) Characterization of a Bacillus thuringiensis strain collection isolated from diverse Costa Rican natural ecosystems. Rev Biol Trop 54:13-27

Attathoma T, Chongrattanameteekula W, Chanpaisanga J, Siriyana R (1995) Morphological diversity and toxicity of delta endotoxin produced by various strains of Bacillus thuringiensis. Bull Entomol Res 85:167-173

Ben-Dov E, Zaritsky A, Dahan E, Barak Z, Sinai R, Manasherob R, Khamraev A, Troittskaya E, Dubitsky A, Berezine N, Margalith Y (1997) Extended screening by PCR for seven cry-group genes from field-collected strains of Bacillus thuringiensis. Appl Environ Microbiol 63:4883-4890

Bernhard K, Jarrett P, Meadows M, Butt J, Ellis DJ, Roberts GM, Pauli S, Rodgers P, Burges HD (1997) Natural isolates of $B$. thuringiensis: worldwide distribution, characterization and activity against insect pests. J Invertebr Pathol 70:59-68

Bravo A, Gill SS, Soberón M. (2007) Mode of action of Bacillus thuringiensis Cry and Cyt toxins and their potential for insect control 49, 423-35. Toxicon

Brown ES, Dewhurst CF (1975) The genus Spodoptera in Africa and the Near East. Bull Entomol Res 65:221-262

Chambers JA, Jelen A, Gilbert MP, Jany CS, Johnson TB, GawronBurke C (1991) Isolation and characterization of a novel insecticidal crystal protein gene from Bacillus thuringiensis subsp. aizawai. J Bacteriol 173:3966-3976

Chari MS, Patel NG (1983) Cotton leaf worm Spodoptera litura (Fabr.): its biology and integrated control measures. Cotton Dev 13:465-482

Chilcott CN, Wigley PJ (1993) Isolation and toxicity of $B$. thuringiensis from soil and insect habitats in New Zealand. J Invertebr Pathol 61:244-247

Christou P, Capell T, Kohli A, Gatehouse JA, Gatehouse AM (2006) Recent developments and future prospects in insect pest control in transgenic crops. Trends Plant Sci 11:302-308

Crickmore N, Zeigler DR, Feitelson J, Schnepf E, Van Rie J, Lereclus D, Baum J, Dean DH (1998) Revision of nomenclature for the Bacillus thuringiensis pesticidal crystal proteins. Microbiol Mol Biol Rev 62:807-813

Crickmore N, Baum J, Bravo A, Lereclus D, Narva K, Sampson K, Schnepf E, Sun M, Zeigler DR (2016) Bacillus thuringiensis toxin nomenclature. http://www.btnomenclature.info

de Escudero IR, Banyuls N, Bel Y, Maeztu M, Escriche B, Muñoz D, Caballero P, Ferré J (2014) A screening of five Bacillus thuringiensis Vip3A proteins for their activity against lepidopteran pests. J Invertebr Pathol 117:51-55

Federici BA (1999) Bacillus thuringiensis in biological control. In: Bellows TS, Gordh G, Fisher TW (eds) Handbook of biological control. Academic Press, Inc., San Diego, pp 575-593

Feitelson JS, Payne J, Kim L (1992) Bacillus thuringiensis: insects and beyond. Nat Biotechnol 10:271-275

Gassmann AJ, Petzold-Maxwell JL, Clifton EH, Dunbar MW, Hoffmann AM, Ingber DA, Keweshan RS (2014) Field-evolved resistance by western corn rootworm to multiple Bacillus thuringiensis toxins in transgenic maize. PNAS 111:5141-5146

Goudar G, Alagawadi AR, Krishnaraj PU, Basavana Goud K (2012) Characterization of Bacillus thuringiensis isolates of Western Ghats and their insecticidal activity against diamond back moth (Plutella xylostella L.). Karnataka J Agric Sci 25:199-202

Gough JM, Akhurst RJ, Ellar DJ, Kemp DH, Wijffels GL (2002) New isolates of B. thuringiensis for control of livestock ectoparasites. Biol Control 23:170-189

Gough JM, Kemp DH, Akhurst RJ, Pearson RD, Kongsuwan K (2005) Identification and characterization of proteins from
Bacillus thuringiensis with high toxic activity against the sheep blowfly, Lucilia cuprina. J Invertebr Pathol 90:39-46

Hastowo S, Lay BW, Ohba M (1992) Naturally occurring $B$. thuringiensis in Indonesia. J Appl Bacteriol 73:108-113

Hire RS, Makde RD, Dongre TK, D'souza SF (2009) Expression, purification and characterization of the Cry2Aa14 toxin from Bacillus thuringiensis subsp. kenyae. Toxicon 54:519-524

Holloway JD (1989) The moths of Borneo: Family Noctuidae, trifine subfamilies: Noctuinae, Heliothinae, Hadeninae, Acronictinae, Amphipyrinae, Agaristinae. Malay Nat J 42:57-226

Ibarra JE, Rincon MC, Orduz S, Noriega D, Benintende G, Monnerat R, Regis L, de Oliveira CMF, Lanz H, Rodriguez MH, Sanchez J, Pena G, Bravo A (2003) Diversity of Bacillus thuringiensis strains from Latin America with insecticidal activity against different mosquito species. Appl Environ Microbiol 69:5269-5274

Ichimatsu T, Mizuki E, Nishimura K, Akao T, Saitoh H, Higuchi K, Ohba M (2000) Occurrence of Bacillus thuringiensis in fresh waters of Japan. Curr Microbiol 40(4):17-20

James C (2013) Global status of commercialized biotech/GM Crops: ISAAA Briefs 46. ISAAA, Ithaca

Juarez-Perez VM, Ferrandis MD, Fructos R (1997) PCR-based approach for detection of novel Bacillus thuringiensis cry genes. Appl Environ Microbiol 63:2997-3002

Laemmli UK (1970) Cleavage of structural proteins during the assembly of the head of bacteriophage T4. Nature (London) 227:680-685

Landen R, Bryne M, Abdel Hameed A (1994) Distribution of $B$. thuringiensis strains in southern Sweden. World J Microbiol Biotechnol 10:45-50

Lenin K, Mariam MA, Udayasuriyan V (2001) Expression of a cry2Aa gene in an acrystalliferous Bacillus thuringiensis strain and toxicity of Cry2Aa against Helicoverpa armigera. World $\mathrm{J}$ Microbiol Biotechnol 17:273-278

Liao C, Heckel DG, Akhurst R (2002) Toxicity of Bacillus thuringiensis insecticidal proteins for Helicoverpa armigera and Helicoverpa punctigera (Lepidoptera: Noctuidae), major pests of cotton. J Invertebr Pathol 80:55-63

Liu T, Guo W, Sun W, Sun Y (2009) Biological characteristics of Bacillus thuringiensis strain Bt11 and identification of its crytype genes. Front Agric China 3:159-163

Maeda M, Mizuki E, Nakamura Y, Hatano T, Ohba M (2000) Recovery of Bacillus thuringiensis from marine sediments of Japan. Curr Microbiol 40:418-422

Manimegalai S, Chandramohan N, Jayarani S (2005) Bioefficiency of new isolates of Bacillus thuringiensis Berliner against lepidopteran pests of economic importance. Indian J Plant Prot 33:48-50

Martin PAW, Travers RS (1989) Worldwide abundance and distribution of B. thuringiensis isolates. Appl Environ Microbiol 55:2437-2442

Martinez C, Caballero P (2002) Contents of cry genes and insecticidal toxicity of $B$. thuringiensis strains from terrestrial and aquatic habitats. J Appl Microbiol 92:745-752

Meadows MP, Ellis DJ, Butt J, Jarret P, Burges HD (1992) Distribution, frequency, and diversity of Bacillus thuringiensis in an animal feed mill. Appl Environ Microbiol 58:1344-1350

Mittermeier RA, Gil PR, Hoffmann M, Pilrim J, Brooks T, Mittermeier CG, Lamoreux J, Fornseca GAB (2005) Hotspots revisited: Earth's biologically richest and most endangered terrestrial eco-regions. University of Chicago, Boston

Mizuki E, Ichimatsu T, Hwang SH, Park YS, Saitoh H, Higuchi K, Ohba M (1999) Ubiquity of Bacillus thuringiensis on phylloplanes of arboreous and herbaceous plants in Japan. J Appl Microbiol 86:979-984

Nagarkatti S, Prakash S (1974) Rearing of Heliothis armigera (Hb.) on artificial diet. Tech Bull Commonw Inst Biol Control $17: 169-173$ 
Neethu KB, Priji P, Unni KN, Sajith S, Sreedevi S, Ramani N, Anitha K, Rosana B, Girish BM, Benjamin S (2015) New Bacillus thuringiensis strain isolated from the gut of Malabari goat is effective against Tetranychus macfarlanei. J Appl Entomol. doi:10.1111/jen.12235

Ozturk F, Acik L, Ayvaz A, Bozdogan B, Suludere Z (2008) Isolation and characterization of native Bacillus thuringiensis strains from soil and testing the bioactivity of isolates against Ephestia kuehniella zeller (Lepidoptera: Pyralidae) larvae. Turk J Biochem 33:202-208

Pardo-López L, Soberón M, Bravo A (2013) Bacillus thuringiensis insecticidal three domain Cry toxins: mode of action, insect resistance and consequences for crop protection. FEMS Microbiol Rev 37:3-22

Patel HK, Jani JJ, Vyas HG (2009) Isolation and characterization of lepidopteran specific Bacillus thuringiensis. Int J Integr Biol 6:121-126

Patel KD, Purani S, Ingle SS (2013) Distribution and diversity analysis of Bacillus thuringiensis cry genes in different soil types and geographical regions of India. J Invertebr Pathol 112:116-121

Porcar M, Martinéz C, Caballero P (2000) Host range and gene contents of Bacillus thuringiensis strains toxic towards Spodoptera exigua. Entomol Exp Appl 97:339-346

Prabagaran SR, Nirmal SJ, Jayachandran S (2002) Phenotypic and genetic diversity of $B$. thuringiensis strains isolated in India active against Spodoptera litura. Appl Biochem Biotechnol 102-103:213-226

Ramalakshmi A, Udayasuriyan V (2010) Diversity of Bacillus thuringiensis isolated from Western Ghats of Tamil Nadu State, India. Curr Microbiol 61:13-18

Reddy VP, Rao NN, Devi PS, Sivaramakrishnan S, Narasu ML, Kumar VD (2013) Cloning, characterization, and expression of a new $c r y 1 A b$ gene from DOR Bt-1, an indigenous isolate of Bacillus thuringiensis. Mol Biotechnol 54:795-802

Reyaz AL, Indra Arulselvi P (2016) Cloning, characterization and expression of a novel haplotype cry2A-type gene from Bacillus thuringiensis strain SWK1, native to Himalayan valley Kashmir. J Invertebr Pathol 136:1-6

Romeis J, Meissle M, Bigler F (2006) Transgenic crops expressing Bacillus thuringiensis toxins and biological control. Nat Biotechnol 24:63-71

Sambrook J, Russell DW (2001) Molecular cloning: a laboratory manual, 3rd edn. Cold Spring Harbor Laboratory Press, Cold Spring Harbor

Sauka DH, Amadio AF, Zandomeni RO, Benintende GB (2007) Strategy for amplification and sequencing of insecticidal cry $1 \mathrm{~A}$ genes from Bacillus thuringiensis. Antonie Van Leeuwenhoek 91:423-430

Schnepf HE, Whiteley HR (1981) Cloning and expression of the Bacillus thuringiensis crystal protein gene in Escherichia coli. Proc Natl Acad Sci USA 78:2893-2897

Schnepf E, Crickmore N, Van Rie J, Lereclus D, Baum J, Feitelson J, Zeigler DR, Dean DH (1998) Bacillus thuringiensis and its pesticidal crystal proteins. Microbiol Mol Biol Rev 62:775-806

Shishir A, Roy A, Islam N, Rahman A, Khan SN, Hoq MM (2014) Abundance and diversity of Bacillus thuringiensis in Bangladesh and their cry genes profile. Front Environ Sci 2:1-10

Shu C, Zhang J, Chen G, Liang G, He K, Crickmore N, Huang D, Zhang J, Song F (2013) Use of a pooled clone method to isolate a novel Bacillus thuringiensis Cry2A toxin with activity against Ostrinia furnacalis. J Invertebr Pathol 114:31-33

Singh PK, Kumar M, Chaturvedi CP, Yadav D, Tuli R (2004) Development of a hybrid delta-endotoxin and its expression in tobacco and cotton for control of a polyphagous pest Spodoptera litura. Transgenic Res 13:397-410

Song F, Zhang J, Gu A, Wu Y, Han L, He K, Chen Z, Yao J, Hu Y, Li G, Huang D (2003) Identification of cryll- type genes from
Bacillus thuringiensis strains and characterization of a novel cry1I- type gene. Appl Environ Microbiol 69:5207-5211

Sumerford DV, Head GP, Shelton A, Greenplate J, Moar W (2013) Field evolved résistance: assessing the problem and ways to move forward. J Encon Entomol 106:1525-1534

Swiecicka I, De Vos P (2003) Properties of B. thuringiensis isolated from bank voles. J Appl Microbiol 94:60-64

Swiecicka I, Fiedoruk K, Bednarz G (2002) The occurrence and properties of Bacillus thuringiensis isolated from free-living animals. Lett Appl Microbiol 34(3):194-198

Tabashnik BE, Finson N, Johnson MW, Heckel DG (1994) Crossresistance to Bacillus thuringiensis toxin Cry1F in the Diamondback moth (Plutella xylostella). Appl Environ Microbiol 60:4627-4629

Tabashnik BE, Mota-Sanchez D, Whalon ME, Hollingworth RM, Carrière Y (2014) Defining terms for proactive management of resistance to Bt crops and pesticides. J Econ Entomol 107:496-507

Thaphan P, Keawsompong S, Chanpaisaeng J (2008) Isolation, toxicity and detection of cry gene in Bacillus thuringiensis isolates in Krabi province, Thailand. Songklanakarin J Sci Technol 30:597-601

Travers RS, Martin PA, Reichelderfer CF (1987) Selective process for efficient isolation of Bacillus spp. Appl Environ Microbiol 53:1263-1266

Unalmis S, Ayvaz A, Yilmaz S, Azizoglu U (2015) Molecular screening and bioactivity of native Bacillus thuringiensis isolates. J Agric Sci Tech 17:1197-1207

Uribe D, Martinez W, Ceron J (2003) Distribution and diversity of cry genes in native strains of $B$. thuringiensis obtained from different ecosystems from Colombia. J Invertebr Pathol 82:119-127

Valicente FH, de Toledo Picoli EA, de Vasconcelos MJV, Carneiro NP, Carneiro AA, Guimarães CT, Lana UG (2010) Molecular characterization and distribution of Bacillus thuringiensis cryl genes from Brazilian strains effective against the fall armyworm, Spodoptera frugiperda. Biol Control 53:360-366

Vidyarthi AS, Tyagi RD, Valero JR, Surampalli RY (2002) Studies on the production of $B$. thuringiensis based biopesticides using wastewater sludge as a raw material. Water Res 36:4850-4860

Vilas-Böas GT, Manoel VFL (2004) Diversity of cry genes and genetic characterization of Bacillus thuringiensis isolated from Brazil. Can J Microbiol 50:605-613

Wang J, Boets A, Van Rie J, Ren G (2003) Characterization of cryl, cry 2 and cry 9 genes in $B$. thuringiensis isolates from China. J Invertebr Pathol 82:63-71

Wei JZ, Hale K, Carta L, Platzer E, Wong C, Fang SC, Aroian RV (2003) B. thuringiensis crystal protein that target nematodes. Proc Natl Acad Sci USA 100:2760-2765

Whalon ME, Mota-Sanchez D, Hollingworth RM, Duynslager L (2007) Spodoptera litura. In: Arthropod pesticide resistance database. Michigan State University. Available via DIALOG. http://www.pesticideresistance.org/search/ 12/282/0/Spodoptera litura

Whitlock VH, Lo MC, Kuo MH, Soong TS (1991) Two new isolates of Bacillus thuringiensis pathogenic to Spodoptera litura. J Invertebr Pathol 58:33-39

Xue J, Liang G, Crickmore N, Li H, He K, Song F, Feng X, Huang D, Zhang J (2008) Cloning and characterization of a novel Cry1A toxin from Bacillus thuringiensis with high toxicity to the Asian corn borer and other lepidopteran insects. FEMS Microbiol Lett 280:95-101

Zheng A, Zhu J, Tan F, Guan P, Yu X, Wang S, Deng Q, Li S, Liu H, Li P (2010) Characterisation and expression of a novel haplotype cry2A-type gene from Bacillus thuringiensis strain JF19-2. Ann Microbiol 60:129-134

Zhong C, Ellar DJ, Bishop A, Johnson C, Lin S, Hart ER (2000) Characterization of $B$. thuringiensis $\delta$-endotoxin which is toxic to insects in three orders. J Invertebr Pathol 76:131-139 